\title{
Middle Management and School Autonomy in Italy: The Case of Teachers as «Instrumental Functions»
}

\section{Lorena Pirola}

Università degli Studi di Macerata - Department of Pedagogy (Italy)

doi: 10.7358/ecps-2015-011-piro_lorena.pirola67@gmail.com

\section{QUADRI INTERMEDI E L'AUTONOMIA SCOLASTICA IN ITALIA: IL CASO DEI DOCENTI «FUNZIONI STRUMENTALI»}

\section{Abstract}

An autonomous school is a complex community. An organizational structure with different roles or "functions" is required in order to achieve its cultural and educational project, and to provide an answer to social needs. Middle professional workers with organizational, planning and coordination duties are expected to support the work of the head teacher and teachers. This article focuses on the "Instrumental Functions" whose origin can be traced back to "Objective Functions» and "System Figures». It also focuses on the teachers who fulfil these functions and who are identified by them. A historical, political analysis highlights that, unlike other countries, there are no proper middle management roles in Italian schools. In fact, besides teaching, Italian teachers are only assigned temporary functional duties. An exploratory survey underscores the importance of the "Instrumental Functions" and identifies their vulnerability: the fragmentation of resources and high staff turnover. What stands out is the demotivation of teachers in carrying out this role, due to an uncertain institutional framework and the lack of training. The risk is that "Instrumental Functions" are considered to be just like any other extra teaching tasks, with the consequent loss of the unique features of these functions. This article concludes that encouraging this kind of professionalism not only allows the organizational development of schools, but also paves the way for teachers' professional development.

Keywords: Autonomy, Instrumental functions, Middle management, Organization, Professional development. 


\section{INTRODUCTION}

Following the Lisbon Treaty, Italy gave its educational system a binding mission: that all students reach their educational goals, essential to granting each person's fundamental rights, promoting social development, and pursuing the objectives of a civil society and active citizenship. The law with regard to school autonomy (Law 59/1997, art. 21, and Presidential Decree 275/1999) was the main instrument in reaching this objective. It transformed the Italian educational system from a centralized, bureaucratic model to a model whereby schools gained a separate legal identity, autonomy in matter of education, organization, research, innovation and development. The "new school» was to have, and presently continues to have, the following features: to be flexible, willing to be open and accessible to its local community, with its own identity ${ }^{1}$, responsible for its own achievements and performance (Berlinguer, 2001). This transformation resulted in the increase of value and significance not only of schools, but also of their professional staff. Schools with autonomy are establishments with a cultural and educational project (Selznick, 1974; Schein, 1985; Lanzalaco, 1995). Their organizational actions follow the logic of loosely coupled systems (Weick, 1976; Von Bertalanffy, 1983; Orton \& Weick, 1990; Zan, 2011) with strong community links (Sergiovanni, 2000; Wenger, 2006) ${ }^{2}$. In such schools, the models of the professional bureaucrat (Mintzberg, 1979; Bonazzi, 1995) and of the independent professional (Orsi, 2002) give way to a collaborative approach to working with management, and sharing organizational and educational leadership competences (Benadusi \& Serpieri, 2000).

According to Law 165/2001, the head teacher plays a key role as "guarantor and is responsible for the services supplied by the school» (Law 150/2009). The head teacher's responsibilities range from management, administrative and organizational areas to human resources, liaising with the local community, cultural and educational functions (Capaldo \& Rondanini, 2005). Teachers remain the professional heart of the school, but the requirements of core skills and abilities have been re-examined: in addition to subject, psychological and pedagogical competences and to those related to methodology and teaching, there are additional organizational-relational competences and other competences concerning research (National Col-

1 The Educational Policy Plan (Piano dell'Offerta Formativa or POF, in Italian) hereinafter abbreviated as EPP.

2 An idea adapted from Cerini, 2010, p. 9. 
lective Agreement ${ }^{3}$ 1998/2001, art. 23; NCA 2002/2005, art. 25), providing evidence and evaluation (NCA 2006/2009, art. 27). Teaching remains the main and most important function of teachers, yet this activity is now supported by new professional working practices: EPP planning and implementation; coordinating working groups; working as part of a team with colleagues from their own institution and others; collaborating with other professionals from local agencies, whether institutional or not; taking on roles that support management. There is an emerging need for new intermediate professional figures ${ }^{4}$ adequately trained to undertake planning, organizational and coordination duties. Though not directly linked to face-to-face teaching and learning, these tasks are strategic for schools internally and for their strengthening ties with the local community (Castoldi, 2002). The Italian position is that of attaining new roles from «the professional patrimony of teachers» (NCA 1998/2001, art. 28).

\section{The CONTEXT OF THE ITALIAN SCHOOL}

An attempt at introducing and recognizing middle management figures in schools can be found in "System Figures" ${ }^{5}$. These are specialized in particular areas, they have a reduced teaching timetable and represent a possible pathway to career progression (NCA 1995/1997, art. 38, par. 7). According to the new logic of school autonomy, the teachers' profiles of specialization pertain to scientific, didactic and pedagogical areas, as well as organizational, management and research. However, to date the SF remain a theory, never put into practice.

«Objective Functions» ${ }^{6}$ were introduced in the NCA of 1998/2001. These are assigned according to school size and typology (not less than three, no more than six), and they include the deputy head teacher. They can be divided into four macro areas of intervention: EPP management, teacher support, student services and intervention, planning educational projects with external institutions and authorities. Interested teachers are appointed by the Board of Teachers, upon receipt of application and a CV. Participation in mandatory training is expected while total exemption from teaching is not possible. At the end of the assignment, the OF teacher is held

\footnotetext{
3 Hereinafter also abbreviated as NCA.

Law 59/1997, art. 21, par. 16.

Hereinafter abbreviated as SF.

6 Hereinafter abbreviated as OF.
} 
accountable for the work completed and responsible for the final outcomes. In line with past experiences, the role of the $\mathrm{OF}$ is not an outright figure of middle management. Its specificity and novelty are, however, unquestionable. This appointment is different from all others in the school. In fact, the appointment is restricted to a limited number of people and the remuneration comes from a different budget, the one which the school normally uses to cover additional activities ${ }^{7}$. The $\mathrm{OF}$ is not a specialized figure and thus continues with all his/her teaching activities. This has a positive impact on fulfilling the assignment since student needs are known and EPP choices are directly put into practice. The annual duration of the appointment ${ }^{8}$ makes it possible to share the benefits of the required organizational competences and educational leadership over a longer period of time, thus promoting and disseminating the development of a new professional culture. It is still not clear why, given the workload, a reduction in teaching hours is not possible, nor why the appointment cannot be extended so as to implement and monitor short- and long-term projects.

The NCA of 2002-2005 ${ }^{9}$ renamed the «Objective Functions» as «EPP Instrumental Functions» and introduced a few significant changes: the Board of Teachers, in line with the EPP, identifies the new functions, defining appointment, number and receiver criteria; the macro areas of intervention are reduced to two: the implementation and management of EPP and the implementation of agreed educational projects with external authorities and institutions. This broadens the decisions that schools can make whilst still underlining the need for nurturing internal activities and liaising with the local community. The participation in mandatory training was also removed as well as any reference to evaluation and professional progression. The reason for instituting "Instrumental Functions» is that of giving schools more autonomy and responsibility: the number and remuneration of each function is no longer set and established at a national level, but is determined by negotiations within the schools according to the duties assigned. These duties may also vary between "Instrumental Functions» of the same school. The risk is that of identifying a high number of functions, with the resulting splitting of responsibilities, fragmentation of resources and loss of the assignment distinctive characteristics (Spinosi, 2005) (Table 1).

\footnotetext{
The contractual gross remuneration anticipated is of 3,000,000 old Italian lira.

8 It is possible to renew the contract.

9 NCA 2002-2005, art. 30. Reconfirmed in the contract 2006-2009, art. 33, currently
} in force. 
Table 1. - Summary of the differences between «System Figures», "Objective Functions» and "Instrumental Functions».

\begin{tabular}{|c|c|c|}
\hline «SYSTEM FiguRES» & «OBJEctive Functions» & «INSTRUMENTAL FUNCTIONS» \\
\hline Profiles of specialization & 4 Areas of intervention & 2 Areas of intervention \\
\hline Not established & 3/6 Appointments & Overall budget \\
\hline $\begin{array}{l}\text { Areas: scientific, didactic, } \\
\text { pedagogical, organizational, } \\
\text { management and research }\end{array}$ & $\begin{array}{l}\text { Competences, assignment } \\
\text { duration (B.o.T.) }\end{array}$ & $\begin{array}{l}\text { Criteria, number and receivers } \\
\text { (B.o.T.) }\end{array}$ \\
\hline $\begin{array}{l}\text { Exemption from teaching } \\
\text { hours }\end{array}$ & $\begin{array}{l}\text { Total exemption from } \\
\text { teaching hours is not possible }\end{array}$ & $\begin{array}{l}\text { Exemption from teaching hours } \\
\text { is not possible }\end{array}$ \\
\hline Not established & $\begin{array}{l}\text { Parameters and frequency } \\
\text { of evaluation (B.o.T.) }\end{array}$ & \\
\hline Not established & Training & \\
\hline Career progression & & \\
\hline
\end{tabular}

Within fifteen years ${ }^{11}$ the Italian education system identified three main figures/functions in order to acknowledge the educational and organizational duties of teachers connected to the development of school autonomy. Each one of these underpins a different organizational model and a distinct culture with regard to how the school is conceived as well as the professional development of teachers. «System Figures» «evoke structures where responsibilities are more defined, more permanent» (Castoldi, 2002, p. 22), based on the clear division of tasks and is part of the classic-rational model. "Objective Functions» come under Weick's loosely coupled system model. These are characterised by a "widespread undertaking of responsibilities and $[. .$.$] a certain inter-changeability and overlapping of tasks» (ibid., p. 16)$ necessary for promoting a certain organizational culture and educational leadership. They represent an opportunity for developing common working practices (Wenger, 2006): work is no longer individual and, generally speaking, the objective function is called upon to coordinate one or more work groups and divulge the results.

The single and standard training offered promotes the development of a professional community: during the academic year 1999/2000, 58,000 teachers on a national level took part in the training provided for OF. This launched «a strong network of professional communication within

\footnotetext{
10 Abbreviation of «Board of Teachers».

11 NCA 1994/1997; NCA1998/2001; NCA 2002/2005.
} 
the specifically created virtual campus» (Dutto, 2000, p. 42). The model which «Instrumental Functions» refer to is not completely clear as they were set up in answer to criticism ${ }^{12}$ regarding a "certain rigidity» ${ }^{13}$ of objective functions in contrast to the principles of school autonomy. An understandable reason for any reference to educational and formative pathways, to a specific profile of competences and to systems and procedures of evaluation designed and validated by the same school cannot be found; a direct consequence of this is the progressive loss of interest and investment, both professional and economic, in new roles.

However, from 1999 to the present day, «Objective» and/or «Instrumental Functions» represent a precious resource for the majority of schools: they uphold the areas which support the overall EPP; increase internal and external communication; make experimentation and innovation possible; have widened the fields of interest; monitor the efficacy of educational projects; and promote the development of a culture of evaluation and self-evaluation (Spinosi, 2005). In summary, these functions have become the backbone of middle management in autonomous schools, which are required to achieve their institutional objectives. They can now be found in the organizational chart of all schools. In some cases, "Objective» and/or "Instrumental Functions» come under management staff, next to collaborators and site managers. In other cases, their role is extended by one or more work groups that they have to coordinate. Their tasks vary from school to school and sometimes these functions represent an opportunity for maintaining continuity with significant past experiences ${ }^{14}$.

The Third IARD ${ }^{15}$ Study noted that out of the one hundred thousand teachers who are involved in school management, $12.8 \%$ cover «Objective» or «Instrumental Functions» duties. Although it is not possible to identify a precise profile for these people, they are generally permanent members of staff with various years of experience who dedicate their time and energy in planning and organizational activities (Cavalli \& Argentin, 2010), mainly without the ambition of becoming head teachers (Fischer et al., 2006). Their commitment, "or rather a certain degree of identification and a certain degree of engagement with their own school» (Rosso, 2007, p. 207), constitutes a strength for the whole school system.

12 Reported by various parties: head teachers' and teachers' trade unions.

13 Number and areas of intervention.

14 Some instrumental functions have taken on duties of IT technician, Psyco-pedagogical Operator, Library services coordinator, Advice and guidance coordinator. These are all figures that were introduced in the 1980s and given exemption from teaching due to illness or staff over-staffing.

15 IARD is an institution which deals with sociological surveys on youth and teachers. 
Bearing in mind that, at this point in time, these activities offer neither a large source of income nor a fast-track within a career in teaching, the most probable hypothesis is that these teachers are led by the desire for personal and professional achievement. This also has a strong impact on the organizational, relational and institutional framework of the school (Calidoni, 2009). In other words, middle management represents an opportunity for the professional development of teachers: «The career cycle of a teacher is not a linear progression from traineeship to retirement [...] [but] a dynamic ebb and flow, where teachers enter and leave career stages in relation to environmental influences, whether personal or organizational» (Marczeley, 1999, p. 37).

A study carried out at a national level during the academic year 2003/2004 and financed by the Italian Ministry of Education, University and Research, identified four organizational figures emerging from the teaching body: deputy head teacher, site managers, teachers as "Instrumental Functions", subject or department coordinators. According to the researchers, the first three represent a clear identity and appear to be now «ready to become a permanent part of an intermediate pool of teachers capable of managing a new school organization following autonomy» (Fischer et al., 2006, p. 213). To this day, this permanent part has not yet been inaugurated and the duties of such an important task continue to be upheld only thanks to a few teachers' sense of responsibility.

The Italian school system does not provide pathways that promote merit and commitment; the only recognized progression route is that of seniority which economically and psychologically mortifies professionals within schools (Fumarco, 2006).

\section{EXPLORATORY STUDY REGARDING DATA OF TEACHERS AS «INSTRUMENTAL FUNCTIONS»}

In order to map data regarding the situational data of teachers as «Instrumental Functions», a qualitative and quantitative exploratory study was carried out.

The first part of the research involves a sample of 325 schools, representing $3 \%$ of the 10,801 state schools present at national level, in order to identify the numeric distribution and the typology of the functions. The data collection ${ }^{16}$ analyzes the EPP and organizational charts for the academic year 2010/2011 published on the school websites.

16 Carried out between early February and the end of May 2011. 


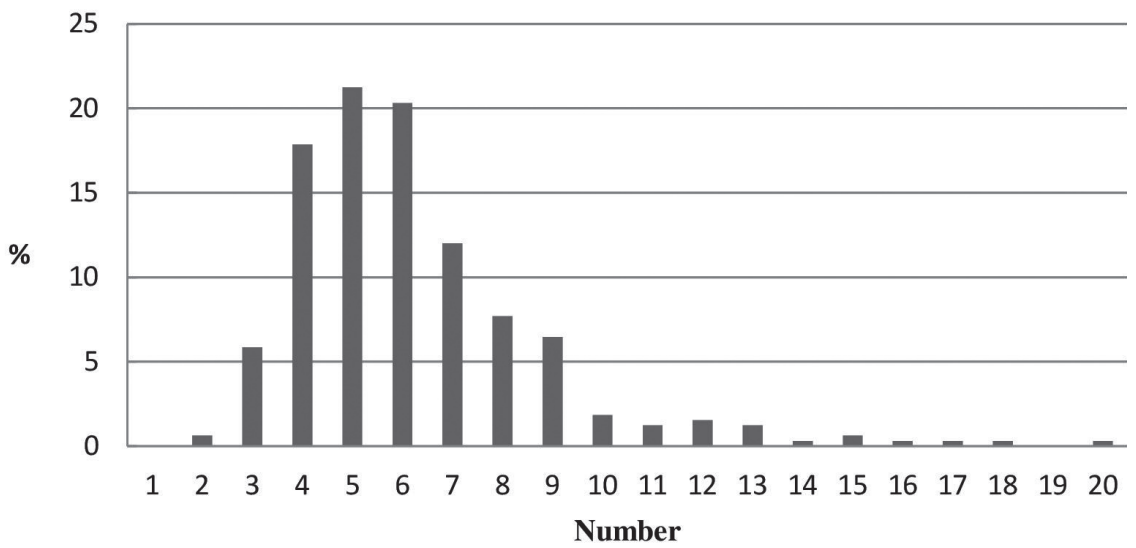

Figure 1. - Number of «Instrumental Functions».

The sample is subdivided into five geographical macro areas (Nord-West, North-East, Centre, South, South and Islands) and according to the typology of schools (Institutions with both nursery and primary schools, First grade secondary schools, Comprehensive Schools, both Second grade secondary schools with a single educational pathway and second grade secondary schools with several educational pathways) (Figure 1).

The schools taken into consideration appoint a minimum number of 2 «Instrumental Functions» (IF) and a maximum of 20 IF. As can be seen in the graph above, the number of IF that reach a significant percentage, over $15 \%$, is as follows: 4 IF (17.85\%), 5 IF (21.23\%), 6 IF (20.31\%). 59\% of the sample chooses between 4 and 6 IF. Above $10 \%$ we instead find those schools with 7 IF (12\%). Schools above 5\% are those with: 3 IF $(5.85 \%)$, 8 IF $(7.69 \%)$, 9 IF $(6.46 \%)$. Between $1 \%$ and $2 \%$ are schools with: 10 IF (1.85\%), 11 IF (1.23\%), 12 IF (1.54\%), 13 IF (1.23\%). School percentages below $1 \%$ are: 2 IF $(0.62 \%), 14$ IF $(0.31 \%), 15$ IF $(0.62 \%), 16$ IF $(0.31 \%)$, 17 IF $(0.31 \%), 18$ IF $(0.31 \%) 20$ IF $(0.31 \%)$. Schools with 1 IF or 0 IF were not identified.

The long list of IF present within schools highlights how a fragmentation of duties occurred during these years. There is another element that must nevertheless be noted: over half of the schools continue to maintain a limited number of IF, from 4 to 6 , generally following the guidelines set out by the NCA of 1999 which anticipated a minimum number of three OF only for the smaller schools. 
Table 2. - Typology of "Instrumental Functions».

\begin{tabular}{lrc}
\hline & NR. & $\%$ \\
\hline EPP & 265 & 13.07 \\
New Technologies & 241 & 11.89 \\
Advice and guidance & 164 & 8.09 \\
Disability & 128 & 6.31 \\
Foreign students & 107 & 5.28 \\
Student services and intervention & 84 & 4.14 \\
Institutional evaluation & 76 & 3.75 \\
EPP and institutional evaluation & 20 & 0.99 \\
Disability and foreign students & 11 & 0.54 \\
Disability, students at risk and foreign students & 8 & 0.39 \\
Ladin & 1 & 0.05 \\
$\ldots$ & $\ldots$ & $\ldots$ \\
\hline Total & 2027 & 100 \\
\hline
\end{tabular}

The second set of data gathered concerns the typology of IF. The list made available in Table 2 is not comprehensive of all typologies identified in this study, but seeks to show the more significant ones. Among these, it was decided to list the following: those with the highest percentages (EPP $13.07 \%$; New Technologies $11.89 \%$, etc.), those with the lowest percentages, because specific to a single school (Ladino 0.05\%), and some of those which reach low percentages because they group together different areas of intervention (EPP and institutional evaluation 0.99\%). The IF Disability $(6.31 \%)$ is associated in some schools with other areas of intervention: Disability and foreign students (0.54\%), Disability, students at risk and foreign students $(0.39 \%)$.

This overall results of the study, reported in the Figure 1 and Table 2, are twofold. Firstly, they suggest that some schools demonstrate knowledge of how to make adequate use of their own resources, therefore identifying a limited number of instrumental functions and specific areas of intervention. Secondly, they also suggest that other schools are fragmenting such resources with regard to the number of IF and areas of intervention. There is an evident need to establish normative parameters, within which each school can actually organise itself so as to best meet the real needs of its local community and users. 
The second part of this field investigation ${ }^{17}$ is qualitative. Semi-structured interviews were used as an instrument, with a particular focus on the following areas: description of the institutional framework of the teacher as «Instrumental Functions» working in that school; identification of the professional profile; training; evaluation; identification of strengths and weaknesses; suggestions for redesigning their role. The sample taken into consideration here, accounting for 5\% of the schools seen above, is of 16 schools: respectively, five from the North and South, and six from the Centre. On the whole, the interviews were carried out with 8 head teachers and 8 "Instrumental Functions» identified from the largest areas observed during the analysis of school websites. Information from 3 deputy teachers, 2 teachers assigned as «Instrumental Functions» and one head teacher was also added to this data.

The overall analysis of information and data collected shows how both the principals and teachers in this sample agree upon the importance of the «intermediate role» held by IF. They concur that this role has many facets (organizational, coordination and planning), it is advantageous to principals and teachers, and it benefits the entire school, internally and in liaising with the local community.

At the same time, the demotivation of teachers in covering this role is highlighted, due to an undefined institutional framework, the absence of a professional profile and adequate training opportunities. The interviewees pointed out some competences that should make up the professional profile of teachers appointed as IF and which should be implemented via transversal training in all areas of intervention: communication-relational, organizational-managerial, and planning.

Another consideration that emerged and that should be looked at separately is the evaluation of the work carried out by the instrumental function, that is, the end of year report presented to the Board of Teachers; even though it has changed over time into a mere formality, the majority of those interviewed did not value this process or feel the need to experiment with a different modality of evaluation. Hence, it is no surprise that the competences of monitoring and evaluation were not indicated for the professional profile of instrumental functions. Another element worthy of note is that the introduction of these figures in schools is not always received with enthusiasm, despite the fact that everybody said nobody could work without them. A teacher stated that the work of IF is sometimes, even today, thwarted by other teachers who somehow see these figures as wanting to climb the career ladder. A head teacher confirmed this, and added that initially even head teachers were opposed to these functions who they felt were taking manage-

17 Carried out between the second half of November 2011 and the end of March 2012. 
ment responsibilities away from them. What emerges from these affirmations is the old logic whereby schools were not an organized community in which all worked together to reach pedagogical objectives, but rather split into two opposing sides: management and teachers.

Teacher motivation in accepting this assignment is either a personal interest in the area of intervention or an interest in the organization and management of the school. According to the principals, these teachers are more active $^{18}$, love working in groups, are not intimidated by innovation and want to better themselves ${ }^{19}$. Nevertheless, it is evident that commitment, when it is not linked to role acknowledgement, risks turning into demotivation and abandonment, thus having direct repercussions on the actual function.

In summary, IF should be more appropriately valued and validated so as to avoid wasting a strategic resource for schools and an opportunity for teachers' professional development. Based on the data reported in this article, further studies are currently being carried out in order to identify possible areas of development which will shortly be made available to the scientific community.

\section{REFERENCES}

Benadusi, L., \& Serpieri, R. (2000). Organizzare la scuola dell'autonomia. Roma: Carocci.

Berlinguer, L. (2001). La scuola nuova. Roma - Bari: Laterza.

Bonazzi, G. (1995). Storia del pensiero organizzativo. Milano: Franco Angeli.

Capaldo, N., \& Rondanini, L. (2005). Dirigere scuole. Le funzioni del dirigente scolastico nella società globale. Trento: Erickson.

Calidoni, P. (2009). Nuove professionalità nella scuola: tra funzione e progetto. In B. Weyland (a cura di), Middle management nella scuola. Bisogni e opportunità di formazione nella scuola della provincia di Bolzano (pp. 123-134). Bolzano: Praxis3.

Castoldi, M. (2002). Introduzione. In M. Castoldi (a cura di), Valutare le Funzioni Obiettivo. Un progetto di ricerca-azione on-line (p. 11). Milano: Franco Angeli.

Cerini, G. (2010). Una nuova generazione di dirigenti scolastici? In G. Cerini (a cura di), Il nuovo dirigente scolastico fra leadership e management (pp. 9-17). Rimini: Maggioli.

18 "They are the persons who put their heart and soul into it», affirms a head teacher.

19 «They do it for personal growth», affirms another head teacher. 
Dutto, M. G. (2000). La formazione continua degli insegnanti: ieri, oggi, domani. Annali della Pubblica Istruzione, 46(1/2), 31-49.

Fischer, L., Fischer, M. G., \& Masuelli, M. (2006). Le figure organizzative emergenti fra gli insegnanti della scuola italiana. Torino: L'Harmattan Italia.

Fumarco, G., Cellerino, N., Tommasina, M. L., \& Torta, M. (2006). Una carriera per gli insegnanti? In G. Fumarco (a cura di), Professione docente. Ruoli e competenze. Roma: Carocci Faber.

Lanzalaco, L. (1995). Istituzioni, organizzazioni, potere. Roma: Carocci.

Marczeley, B. (1999). Personalizzare lo sviluppo professionale degli insegnanti. Trento: Erickson.

Mintzberg, H.(1979). The structuring of organizations. Englewood Cliffs: Prentice Hall.

Orsi, M. (2002). Scuola, organizzazione, comunità. Nuovi paradigmi per la scuola dell'autonomia. Brescia: La Scuola.

Orton, J. D., \& Weick, K. E. (1990). Loosely coupled systems: A reconceptualization. Academy of Management Review, 15(2), 203-223.

Petrucci, C. (2002). Le funzioni obiettivo: verso un nuovo modello organizzativo. In M. Castoldi (a cura di), Valutare le Funzioni Obiettivo. Un progetto di ricercaazione on-line (pp. 15-28). Milano: Franco Angeli.

Rosso, G. (2007). Gestire una scuola tramite lo sviluppo di comunità di pratica. In G. Alessandrini (a cura di), Comunità di pratica e società della conoscenza (pp. 200-210). Roma: Carocci.

Schein, E. H. (1985). Organizational culture and leadership. San Francisco: JosseyBass.

Selznick, P. (1974). La leadership nelle organizzazioni. Milano: Franco Angeli.

Sergiovanni, T. J. (2000). Costruire comunità nelle scuole. Roma: LAS.

Spinosi, M. (2005). Funzioni Strumentali. In S. Auriemma (a cura di), Repertorio. Dizionario normativo della scuola (pp. 385-390). Napoli: Tecnodid.

Trivellato, P., \& Triventi, M. A. (2010). Non solo insegnamento. In A. Cavalli \& G. Argentin (a cura di), Gli insegnanti italiani: come cambia il modo di fare scuola. Terza indagine dell'Istituto IARD sulle condizioni di vita e di lavoro nella scuola italiana. Bologna: il Mulino.

Von Bertalanffy, L.(1983). Teoria Generale dei Sistemi: fondamenti, sviluppo, applicazioni. Milano: Mondadori.

Weick, K. E. (1976). Educational organizations as loosely coupled systems. Administrative Science Quarterly, 21, 1-19.

Wenger, E. (2006). Comunità di pratica. Apprendimento, significato e identità. Milano: Raffaello Cortina.

Zan, S. (2011). Le organizzazioni complesse. Logiche d'azione dei sistemi a legame debole. Roma: Carocci. 


\section{Riassunto}

Le istituzioni scolastiche autonome si configurano come comunità complesse che per poter realizzare il proprio progetto culturale ed educativo e per rispondere ai bisogni sociali necessitano di una struttura organizzativa con funzioni differenziate. A supporto dell'azione del dirigente scolastico e dei docenti si avverte l'esigenza di figure professionali intermedie con mansioni organizzative, di progettazione e coordinamento. Il focus di attenzione è il docente titolare di "Funzione Strumentale», la cui origine risale alle "Funzioni Obiettivo" e alle "Figure di Sistema". Un'analisi storico-politica consente di evidenziare che, a differenza di altri Paesi, la scuola italiana non contempla ruoli di "middle management» ma tende ad attribuire ai docenti stessi, oltre all'attività di insegnamento, incarichi funzionali a tempo definito. Un'indagine esplorativo-ricognitiva conferma l'importanza del ruolo ma al tempo stesso ne evidenzia i limiti: parcellizzazione delle risorse e turn-over nell'assegnazione dell'incarico sono i due indicatori principali. Risaltano la demotivazione dei docenti a ricoprire tale funzione a causa dei contorni istituzionali indefiniti e l'assenza di formazione. Il rischio è l'assimilazione alle altre attività aggiuntive all'insegnamento e la conseguente perdita di specificità della funzione. La promozione di tali professionalità rappresenta una possibilità non solo per lo sviluppo organizzativo della scuola ma anche per lo sviluppo professionale dei docenti.

Parole chiave: Autonomia, Funzione Strumentale, Middle management, Organizzazione, Sviluppo professionale. 